Published Volume 20 Nomor 2, Oktober, 2019, 134-145

Jurnal Ilmiah Manajemen dan Bisnis

ISSN 1693-7619 (print) | ISSN 2580-4170 (online), http://jurnal.umsu.ac.id/index.php/mbisnis

\title{
Anteseden Keterikatan Karyawan
}

\author{
Maemar Chadavid Syamtar ${ }^{1)^{*}}$, Iin Mayasari ${ }^{2)}$ \\ Program Studi Manajemen, Universitas Paramadina \\ Jl. Gatot Subroto Kav. 97-98, Mampang, Jakarta Selatan, Indonesia \\ *Email:maemar.chadavid@gmail.com
}

\begin{abstract}
Artikel Info
\section{ABSTRAK}

Dikirim:

27 Juni 2019

Revisi:

15 Agustus 2019

Diterima:

27 September 2019

Tujuan penelitian ini adalah untuk mengetahui hubungan antara sejumlah anteseden yaitu karakteristik pekerjaan (job characteristic), rewards dan pengakuan, keadilan distributif (distributive justice), keadilan prosedural (procedural justice), perceived organizational support (POS), dan perceived supervisor support (PSS) terhadap engagement pekerjaan dan engagement organisasi. Penelitian ini melibatkan 81 responden yang bekerja di Universitas X. Sebanyak 54 persen responden adalah perempuan dan mayoritas berprofesi sebagai dosen (57 persen). Penelitian ini menggunakan pengukuran engagement pekerjaan dan organisasi yang dikembangkan oleh Saks (2006) untuk penelitiannya. Hasil uji menunjukkan bahwa semua anteseden tidak signifikan memengaruhi engagement pekerjaan sementara hanya POS yang positif signifikan memengaruhi engagement organisasi. Temuan tersebut menegaskan bahwa engagement pekerjaan dan organisasi adalah dua konstruk yang berbeda dan telah berkontribusi dalam memperkuat penelitian dalam bidang manajemen khususnya pada studi engagement.
\end{abstract}

Kata kunci: Anteseden, Engagement Pekerjaan, Engagement Organisasi

\section{Anteseden Employee Engagement}

\begin{abstract}
The purpose of this study was to test a relationship between antecedents: job characteristic, rewards and recognitions, distributive justice, procedural justice, perceived organizational support (POS), and perceived supervisor support (PSS) to job and organization engagements. This research was completed by 81 respondents working in University X. 54 percent respondent were female and majority is a lecturer (57 percent). This research included measures of job and organization engagement as well as the antecedents of engagement who developed by Saks (2006) for his research. The findings of this research is all antecedents' not significant influence job engagement while only POS positive significant influence organizational engagement. Those findings proved that job and organizational engagement are two different construct and contributed to strengthening research on management especially in engagement study.
\end{abstract}

Keywords: Antecedents, Job Engagement, Organizational Engagement

Cara Sitasi :

Syamtar, M. C., \& Iin Mayasari, I. (2019). Anteseden Keterikatan Karyawan. Jurnal Ilmiah Manajemen dan Bisnis, 20(2), 134-145. https://doi.org/10.30596/jimb.v20i2.3396. 


\section{PENDAHULUAN}

Employee engagement, merupakan topik yang sedang populer dikalangan praktisi SDM, perusahaan konsultan, dan akademisi (Saks, 2006; Gruman dan Saks, 2011). Gruman dan Saks (2011) percaya bahwa cara terbaik untuk meningkatkan manajemen kinerja dalam organisasi saat ini adalah fokus pada employee engagement. Richman (2006) mengklaim bahwa employee engagement memprediksi outcomes karyawan, kesuksesan organisasi, dan kinerja keuangan (Saks, 2006). Ketika karyawan memiliki tingkat engagement yang tinggi dalam organisasi, maka produktivitas dan kinerja organisasi pun akan tinggi (Konrad, 2006). Karyawan yang terikat mungkin lebih produktif dibandingkan dengan mereka yang tidak (Saks, 2006).

Schaufeli, Bakker, dan Salanova (2006) menyatakan bahwa engagement adalah hal yang penting untuk organisasi kontemporer mengingat banyak tantangan yang dihadapi, salah satunya adalah menciptakan keunggulan kompetitif. Menurut Macey et al. (2009) organisasi dapat memperoleh keunggulan kompetitif melalui employee engagement (Gruman dan Saks, 2011) yang pada akhirnya secara langsung memengaruhi kinerja perusahaan (Harter et al., 2002; Sadeli, 2011).

Hasil yang lebih spesifik tentang employee engagement di Indonesia dilaporkan oleh Tower Watson. Berdasarkan hasil survei yang bertajuk Global Workforce Study 2012 (GWS 2012), karyawan di Indonesia memiliki tingkat engagement yang rendah. Hasil survei tersebut menjelaskan bahwa hampir dua pertiga (sekitar 67 persen) karyawan di Indonesia tidak memiliki hubungan yang kuat pada perusahaan. GWS 2012 menemukan bahwa 27 persen karyawan Indonesia yang di survei mengatakan bahwa dalam dua tahun mendatang kemungkinan akan meninggalkan pekerjaan dan perusahaan. Sebanyak 42 persen karyawan yang disurvei yakin harus meninggalkan perusahaan untuk meningkatkan karir pada masa mendatang. Sekitar 38 persen dari karyawan yang tidak memiliki engagement cenderung akan meninggalkan pekerjaan dalam waktu dua tahun. Sebanyak 21 persen karyawan yang terikat juga akan meninggalkan perusahaan dalam periode yang sama.

Hasil survei di atas akan menjadi hal yang membahayakan bagi perusahaan di Indonesia. Terlebih apabila karyawan yang tidak terikat dan memutuskan untuk meninggalkan perusahaan adalah karyawan yang memiliki talenta terbaik. Berdasarkan laporan Global Talent 2021 , kelompok talenta akan bergerak dari pasar negara industri ke negara-negara berkembang. Pada beberapa dekade mendatang, persentase bakat-bakat berpendidikan tinggi akan meningkat 60 persen di negara-negara E7. Dampak dari distribusi talenta secara global akan dramatis karena sebesar 54 persen lulusan perguruan tinggi berasal dari negaranegara emerging markets. Hasil tersebut menempatkan Indonesia sebagai negara emerging market ketiga terbesar yang menyumbangkan lulusan perguruan tinggi dengan talenta terbaik

Keputusan mereplikasi penelitian Saks, (2006) didasarkan pada beberapa pertimbangan. Pertama adalah karena originalitas penelitian Saks (2006). Saks (2006) merupakan peneliti pertama yang melakukan pembedaan antara engegement pekerjaan dan organisasi serta pengujian anteseden dan konsekunsi employee engagament. Saks (2006) melakukan pengujian model untuk mengetahui peran employee engagement sebagai mediasi hubungan anteseden terhadap konsekuensi. Kedua, bila membuka halaman scholar.google.com, penelitian Saks (2006) dijadikan bahan rujukan sekitar 4.309 dan menjadi salah satu penelitian yang paling banyak dijadikan rujukan dalam hal penelitian employee engagement. Hal tersebut mendorong peneliti untuk melakukan replikasi secara menyeluruh terhadap penelitian Saks (2006) untuk menguji kembali hasil penelitian tersebut. Hasil penelitian ini diharapkan mampu memberikan gambaran 
lain tentang cakupan engagement. Melalui pemilihan sampel dari satu organisasi diharapkan dapat memperkaya temuan tentang pentingnya engagement khusunya pada sektor pendidikan.

Penelitian ini akan dilaksanakan dengan studi kasus di sebuah universitas di Jakarta. Keputusan mengambil bidang pendidikan sebagai sampel penelitian didasarkan atas kekhawatiran peneliti terkait rendahnya tingkat engagement di lembaga pendidikan di Indonesia yang pada akhirnya akan mempengaruhi lulusan perguruan tinggi. Pemilihan Universitas $\mathrm{X}$ sebagai sampel penelitian didasarkan atas latar belakang adanya permasalahan internal universitas. Peneliti menduga bahwa Universitas $\mathrm{X}$ memiliki permasalahn terhadap tingginya tingkat pengunduran diri karyawan dan rendahnya tingkat rewards. Peneliti kerap mendengar sharing dari sejumlah karyawan bahwa gaji yang mereka terima cukup rendah bila dibanding staf level yang sama di universitas lain. Faktor gaji ditengarai menjadi salah satu alasan kurangnya kinerja karyawan dan tingginya keinginan untuk mencari pekerjaan lain. Selain itu, selama ini penelitian terkait engagement lebih banyak dilakukan pada industri non-pendidikan yang pada umumnya profit oriented, sehingga perlu banyak penelitian apakah engagement juga berlaku dalam bidang pendidikan. Hasil penelitian ini akan peneliti sajikan lebih lanjut pada bagian di bawah ini.

Mengingat luasnya pembahasan tentang employee engagement dan dengan mempertimbangkan keterbatasan peneliti, maka peneliti membatasi masalah penelitian ini pada anteseden employee engagement berdasarkan penelitian Saks (2006). Anteseden employee engagement yang diteliti olek Saks (2006) antara lain: karakteristik pekerjaan (job characteristic), rewards dan pengakuan, keadilan distributif (distributive justice), keadilan prosedural (procedural justice), perceived organizational support (POS), perceived supervisor support (PSS).
Employee engagement, adalah topik baru yang populer dikalangan praktisi SDM, perusahaan konsultan, dan akademisi (Saks, 2006; Gruman and Saks, 2011). Employee engagement merupakan faktor utama dalam kesuksesan eksekusi strategi bisnis (Wellins et al., 2005) dan dinilai penting terutama dalam hal apakah employee engagement mampu memengaruhi dan memberikan kontribusi bagi keberhasilan organisasi (Saks, 2006; Lawler III, 2008). Employee engagement sering disebut sebagai "hottest topics in management" (Wellbourne, 2007; Pati and Kumar, 2010). Karyawan yang percaya pada tujuan perusahaan merasa bangga untuk bekerja di perusahaan dan mempersiapkan diri untuk bergabung ke dalam upaya ekstra mencapai tujuan tersebut dan akan tinggal dengan organisasi. Tidak mengherankan bila engagement telah terbukti sebagai penghubung ke ukuran kinerja bisnis seperti turnover, layanan pelanggan dan return on investment (Towers Perrin, 2005; Sadeli, 2011).

Definisi employee engagement sering tumpang tindih (Saks, 2006). Beberapa hasil penelitian akademik mendefinisikan, employee engagement dengan ketelitian yang tinggi, bukan hanya sekedar energi dan gairah, serta mencari anteseden dan konsekuensi dari employee engagement (Saks, 2006). Menurut Catteeuw et al. (2007) engagement adalah tingkatan kepuasan karyawan terhadap pekerjaan dan merasa berharga, pekerja yang engaged akan bertahan diperusahaan lebih lama dan menjadi lebih cerdas secara berkelanjutan, lebih efektif untuk menambahkan nilai bagi institusinya (Wulandari dan Gustomo, 2012).

Harter et al. (2002); Gruman and Saks, 2011) mendefinisikan employee engagement sebagai engagement individu, kepuasan, dan antusiasme untuk bekerja. Employee engagement adalah sejauh mana seorang individu penuh perhatian dan diberdayakan dalam pelaksanaan peranannya sebagai seorang karyawan (Saks, 2006). Right management (2009) mendefinisikan employee 
engagement dengan empat faktor yang menentukan: pertama adalah komitmen terhadap pekerjaan dan organisasi, kedua adalah kebanggaan terhadap pekerjaan dan organisasi, ketiga adalah kesediaan untuk mendukung keuntungan dan manfaat dari pekerjaan dan organisasi, dan keempat adalah kepuasan terhadap pekerjaan dan organisasi.

Employee engagement adalah ketika sebuah organisasi memperlakukan karyawan dengan baik (sepenuhnya mendukung karyawan dengan menanggapi masalah, mendengarkan pendapat), karyawan merespon dengan berfokus dan memberikan kontribusi lebih untuk pekerjaan dan organisasi, dan meningkatkan engagement yang mengarah pada perilaku yang lebih positif dan produktif (Eisenberger, Fasolo, LaMastro, 1990) serta memengaruhi produktivitas dan kinerja organisasi yang akan meningkat (Konrad, 2006). Engagement melibatkan tingkat energi yang tinggi dan identifikasi suatu pekerjaan, bertentangan dengan disengagement yang melibatkan tingkat energi yang rendah (Schaufeli and Salanova, 2007 ; Gruman and Saks, 2011).

Saks (2006) menjelaskan terdapat dua jenis employee engagement yaitu: engagement organisasi (organizational engagement) dan engagement pekerjaan (job engagement). Engagement organisasi adalah kebanggaan karyawan atau kegembiraan menjadi bagian dari organisasi. Karyawan terikat penuh secara fisik bersemangat, emosional, mental fokus, dan merasa selaras dengan tujuan perusahaan tersebut (Wilson, 2009). Sedangkan engagement pekerjaan adalah memenuhi pekerjaan dengan keadaan pikiran yang ditandai dengan semangat (vigour), dedikasi, dan absorption (Schaufeli et al., 2006). Semangat mengacu pada tingkat energi yang tinggi dan ketahanan mental di tempat kerja, ditandai dengan motivasi untuk berinvestasi dan bertahan dalam keadaan sulit sekalipun. Dedikasi berarti menjadi sangat terlibat dalam suatu pekerjaan, antusiasme, inspirasi, kebanggaan, dan tantangan. Absorption mengacu pada keadaan menghayati secara mendalam dan berkonsentrasi pada pekerjaan. Lebih lanjut, menurut Schaufeli et al. (2006) ketika menghayati secara mendalam pekerjaan, karyawan akan mengalami waktu yang berlalu dengan cepat dan merasa sulit untuk melepaskan diri dari pekerjaan.

Engagement pekerjaan adalah konsep yang pada intinya terdiri atas keterlibatan yang tinggi, energi afektif, dan kehadiran di tempat kerja (Macey dan Schneider, 2008 dalam Sonnentag, Mojza, Binnewies, dan Scholl, 2008). Engagement pekerjaan menjelaskan fokus karyawan, semangat, energi dan waktu untuk menyelesaikan pekerjaan, akibatnya, karyawan yang engaged menjadi lebih produktif dibandingkan dengan karyawan yang disengaged (Gruman dan Saks, 2011). Pendapat lain mengatakan bahwa engagement pekerjaan merupakan pengalaman kerja yang positif dan memengaruhi dalam kehidupan organisasi yang menghasilkan berbagai manfaat bagi organisasi (Park dan Gursoy, 2012 dalam Yakin dan Erdil, 2012).

Karakteristik pekerjaan (job characteristics) dikembangkan oleh Hackmand dan Oldham (1980). Karakteristik pekerjaan merupakan aspek internal dari suatu pekerjaan yang mengacu pada isi dan kondisi pekerjaan (Hackman and Oldham, 1980). Ivancevich and Donnely (2002) menjelaskan bahwa karakteristik pekerjaan merupakan isi pekerjaan yang dirasakan oleh karyawan sebagai pemegang pekerjaan (Mulyadi, 2012).

$$
\text { Hackman dan Oldham (1980) }
$$
menemukan bahwa ada beberapa faktor dalam karakteristik pekerjaan yaitu: variasi keterampilan (skill variety), nilai penting tugas (task significance), identitas tugas (task identity), otonomi (autonomy), dan umpan balik (feedback) (Saks, 2006). Variasi keterampilan adalah banyaknya keterampilan yang diperlukan seorang karyawan dalam menyelesaikan pekerjaan, yang melibatkan sejumlah keterampilan individu dan bakat (Djastuti, 2011). Identitas tugas adalah tugas 
yang dapat diidentifikasi dengan melihat keterlibatan dan kesempatan karyawan dalam melaksanakan pekerjaan (Djastuti, 2011). Signifikansi tugas adalah arti penting suatu pekerjaan dan dampak substansial atas kehidupan atau pekerjaan orang lain, baik dalam lingkup organisasi internal maupun eksternal (Djastuti, 2011).

Karyawan yang melibatkan variasi keterampilan, identitas tugas, dan signifikansi tugas yang tinggi akan menganggap pekerjaan mereka sangat berarti (Djastuti, 2011). Tingkat otonomi yang tinggi akan membangkitkan rasa tanggung jawab yang lebih besar dan apabila disediakan umpan balik yang memadai maka karyawan akan mengembangkan suatu pemahaman yang berguna mengenai peranan dan fungsi mereka dengan lebih baik (Djastuti, 2011).

Beberapa penelitian menunjukkan bahwa karakteristik pekerjaan berpengaruh positif dan signifikan terhadap kinerja (Gunastri, 2009), motivasi (Subyantoro, 2009), kepuasan kerja (Subyantoro, 2009; Frimansah dan Santy, 2011), kepuasan kerja pegawai negeri sipil (PNS) (Firman, 2011), komitmen organisasi (Djastuti, 2011), OCB (Santoso, 2011).

POS merupakan representasi persepsi karyawan terhadap komitmen organisasi (Johlke, Stamper and Shoemaker, 2002). POS adalah sebuah konsep yang menjelaskan hubungan antara suatu organisasi dan karyawan. POS mengukur karyawan merasa dukungan yang diberikan oleh organisasi. Karyawan dengan POS yang tinggi akan memiliki kepuasan kerja yang tinggi pula (Yoon, Seo and Yoon, 2004). Karyawan yang diperlakukan dengan baik akan menjadi lebih berkomitmen terhadap organisasi (Aselage and Eisenberger, 2003) melebihi tanggung jawab secara eksplisit yang diperlukan dalam pekerjaan, dan untuk merespon secara fleksibel segala peluang dan masalah yang dihadapi organisasi (Aselage and Eisenberger, 2003).

POS pada dasarnya menggambarkan hubungan antara suatu organisasi atau atasan dengan karyawan. Dasar untuk hubungan tersebut adalah social exchange theory/teori pertukaran sosial (SET) (Saks, 2006; Cole, Bruch, dan Vogel, 2006; Shore dan Tetrick, 1991 dalam Sadeli, 2011). SET menjelaskan bahwa semakin besar dukungan organisasi yang dirasakan oleh karyawan, maka effortoutcome yang diharapkan dari karyawan juga semakin tinggi (Eisenberger, et al., 1990).

Dukungan yang berasal dari atasan dikenal dengan istilah perceived supervisor support (PSS). Menurut Kottke and Sharafinski (dalam Eisenberger et al., 2002) PSS adalah pandangan umum yang dikembangkan bawahan terkait dengan atasan menilai kontribusi dan peduli terhadap kesejahteraan mereka. Atasan langsung yang memperlakukan karyawan dengan penuh perhatian menyebabkan persepsi karyawan terhadap organisasi menjadi positif.

Menurut Levinson (Eisenberger et al., 2002) atasan bertindak sebagai perwakilan organisasi yang memiliki tanggung jawab untuk mengarahkan dan mengevaluasi kinerja sehingga bawahan dapat melihat orientasi dukungan atasan terhadapnya sebagai indikasi dari dukungan organisasi. Stinglhamber et al., (2006) menjelaskan bahwa PSS mengacu pada persepsi karyawan mengenai tingkat dan kualitas dukungan supervisor/pimpinan yang tersedia (Sawers, 2011). Dukungan atasan menurut House (Andaleeb, 2006) mengacu pada kepedulian sosio-emosional atasan dan menunjukkan tingkatan mengenai seberapa besar atasan membentuk iklim yang menunjang dukungan psikologis, saling percaya, kekerabatan (friendliness), dan saling membantu (helpfulness).

Berdasarkan pandangan para ahli di atas, dapat ditarik kesimpulan bahwa PSS adalah pandangan umum atau persepsi yang dibentuk karyawan terhadap tingkatan nilai dan kualitas dukungan/perhatian yang tersedia dan ditunjukkan oleh atasan langsung dalam bentuk menghargai kontribusi, mendukung, dan peduli terhadap kesejahteraan mereka. Tingkatan nilai dan kualitas dukungan yang diberikan oleh atasan 
dikembangkan sebagai hasil dari penilaian atasan terhadap kontribusi karyawan terhadap organisasi. Sebagai balasan, karyawan akan mencurahkan perhatian terhadap pekerjaan dalam bentuk perilaku positif.

Beberapa penelitian melibatkan anteseden untuk PSS yaitu: POS (Eisenberger et al., 2002), rewards dan kondisi kerja (Rhoades and Eisenberger, 2002), dan keadilan (Rhoades and Eisenberger, 2002). Meskipun POS merupakan anteseden dari PSS, namun tingkat dukungan yang dirasakan berbeda antar organisasi (Rhoades and Eisenberger, 2002). Eisenberger et al. (2002) menemukan bahwa PSS positif berhubungan dengan perubahan karyawan dalam POS dari waktu ke waktu. Ardianto, (2009) menemukan bahwa PSS memiliki pengaruh positif terhadap komitmen setelah dimediasi oleh POS.

Menurut McKenna, (2001), rewards dapat dibagi menjadi komponen intrinsik dan ekstrinsik. Rewards ekstrinsik (misalnya uang dan keuntungan material lainnya) berasal dari sumber-sumber yang berada di luar individu. Rewards intrinsik dapat digambarkan sebagai perasaan prestasi, tanggung jawab, atau pertumbuhan pribadi (kaitannya dengan teori motivasi). Sehingga dapat disimpulkan bahwa rewards adalah keuntungan material dan nonmaterial yang diperoleh karyawan dari organisasi. Jika organisasi menuntut lebih kepada karyawan, maka organisasi juga harus secara eksplisit memberikan rewards kepada karyawan yang telah memberikan perhatian ekstra (Baron, 1983 Roberts, 2005).

Menurut Armstrong and Murlis (2005) dan Milkovich and Newman (2008), pada organisasi moderen, rewards terdiri dari dua bagian yaitu financial reward dan nonfinancial reward (Chiang and Birtch 2012). Financial reward termasuk di dalamnya adalah reward tetap (gaji dan tunjangan) dan variabel reward (insentif yang bergantung pada individu, kelompok, atau kinerja organisasi). Non-financial reward mencakup manfaat nyata yang disediakan dan dikendalikan oleh perusahaan (Kanungo and
Hartwick, 1987; Chiang and Birtch 2012). Non-financial reward tidak menguntungkan karyawan dalam arti moneter, contohnya pengakuan, pengaturan alternatif pekerjaan, dan pelatihan dan pengembangan.

Rewards secara substansial terkait dengan turnover, dengan kata lain, karyawan yang puas dengan rewards organisasi akan percaya bahwa kehilangan reward kompetitif menjadi mahal nilainya dan mungkin tidak akan menemukan kompensasi tersebut di tempat lain, sehingga mereka memilih untuk tetap tinggal (Foong-ming, 2008). Rewards yang diberikan organisasi tergantung pada kinerja dan konstribusi seorang karyawan (Foong-ming, 2008).

Lawler (1981), Milkovich and Wigdor (1991), dan Zenger (1992) sepakat bahwa rewards sangat efektif dalam menarik talent dan mempertahankan kinerja yang baik (Foong-ming, 2008). Reward dan pengakuan diberikan sebagai tanggapan atas persepsi manajer terhadap kinerja baik dari karyawan (Ali and Ahmed, 2009). Program rewards merupakan alat manajemen yang diharapkan dapat berkontribusi dalam memengaruhi perilaku individu atau kelompok dalam rangka efektivitas perusahaan (Ali and Ahmed, 2009) dan untuk mencapai dan mempertahankan keunggulan kompetitif (Lawler, 2003; Chiang and Birtch, 2012).

Beberapa penelitian telah dilaksanakan untuk mengetahui pengaruh dan hubungan reward terhadap sejumlah variabel. Berdasarkan penelitian reward memediasi POS dengan komitmen afektif organisasi (Rhoades et al., 2001) dan komitmen organisasi (Ardianto, 2009). Witt and Nye (1992) dalam penelitiannya membuktikan bahwa ada hubungan antara persepsi kewajaran tingkat rewards dan promosi dengan kepuasan kerja (Riyanto, 2008). Penelitian lain melaporkan bahwa rewards dan pengakuan berpengaruh positif signifikan terhadap kepuasan karyawan (Ali and Ahmed, 2009), memotivasi karyawan bertahan di perusahaan (Ivanevich, 2004; 


\section{Jurnal Ilmiah Manajemen dan Bisnis}

ISSN 1693-7619 (print) | ISSN 2580-4170 (online), http://jurnal.umsu.ac.id/index.php/mbisnis

Wulandari dan Gustomo, 2012), dan memengaruhi kinerja (Pahlevi, 2012)

Perspektif kontrol instrumental berpendapat bahwa prosedur-prosedur yang digunakan oleh organisasi akan dipersepsikan lebih adil manakala individu yang terpengaruh oleh suatu keputusan memiliki kesempatan-kesempatan untuk memengaruhi proses-proses penetapan keputusan atau menawarkan masukan (Pareke, 2003; Nugraheni dan Wijayanti, 2009). Keadilan prosedural didefinisikan sebagai keadilan yang dirasakan melalui kebijakan dan prosedur yang digunakan dalam membuat keputusan dalam lingkungan kerja (Greenberg, 1990; Kadaruddin, Kadir, dan Mardiana, 2010).

Tyler (1989) telah mengonsepsikan keadilan prosedural sebagai hubungan antara pembuat keputusan dengan individu yang terlibat dalam proses pengambilan keputusan (Kuncoro, 2012) dan pengimplementasian keputusan (Bartol et al, 2001; Kuncoro, 2012). Berdasarkan pandangan para ahli di atas, dapat disimpulkan bahwa keadilan prosedural adalah bentuk keadilan yang dirasakan oleh karyawan dari proses, sehubungan dengan kebijakan dan prosedur yang timbul dari hubungan antara pembuat keputusan dengan karyawan.

Beberapa penelitian telah dilakukan dan menunjukkan hasil bahwa keadilan prosedural berpengaruh signifikan terhadap kesejahteraan karyawan (Mustafa, 2008), kepuasan kerja (Mustafa, 2008; Listyantara, 2009; Folger dan Konovsky, 1989; Handi dan Suhariandi, 2009; Cohen-Carash and Spector, 2001; Spector, 2012:200; Kadaruddin et al., 2012), kepuasan kenaikan gaji (Handi dan Suhariandi, 2009), OCB (Wulandari, 2011), kinerja (Nugraheni dan Wijayanti, 2009; Spector, 2012) dan intention to quitting (Spector, 2012).

Keadilan distributif dalam psikologi meliputi segala bentuk distribusi antar anggota (Faturrochman, 2002). Menurut Adams (1965), keadilan distributif pada dasarnya dapat tercapai bila penerimaan dan masukan antara dua orang sebanding (Faturrochman, 2002). Akibatnya, persepsi tentang keadilan hasilnya tidak hanya akan berhubungan dengan ukuran absolut, tetapi juga akan berdasarkan pada satu ukuran atau lebih, yaitu perbandingan sosial. Hasil tersebut berkenaan dengan perbandingan atau standar dan pengaruh kekuatan perasaan maupun penilaian adil atau tidaknya hasil yang didapat (Sabbagh, 2003).

Keadilan distributif menekankan pada kesamaan dan kehawatiran akan wajar atau tidak rewards yang diterima dengan karyawan lain (Spector, 2012:200). Berdasarkan pandangan para ahli di atas, dapat disimpulkan bahwa keadilan distributif didefinisikan sebagai persepsi yang merujuk pada penilaian tentang keadilan atau kesamaan dan kekhawatiran akan wajar atau tidak hasil yang diterima oleh karyawan atas input yang diberikan terhadap kesejahteraan mereka.

Penelitian mengenai keadilan distributif menunjukkan bahwa persepsi individu mengenai keadilan terhadap distribusi yang diperoleh memengaruhi sikap dan perilaku karyawan (Tjahjono, 2007). Beberapa penelitian menunjukkan bahwa keadilan distributif berpengaruh positif signifikan terhadap kesejahteraan karyawan (Mustafa, 2008), kinerja (Nugraheni dan Wijayanti, 2009; Spector, 2012:200), kepuasan kerja (Mustafa, 2008; Listyantara, 2009; Kadaruddin et al., 2012), dan OCB (Tuasela, 2013).

Pekerjaan dengan karakteristik pekerjaan yang tinggi memberikan individu ruang dan insentif untuk mengarahkan diri mereka sendiri ke dalam pekerjaan dan menjadi lebih engaged (Saks, 2006). Kondisi beban kerja dan kontrol dari Maslach et al. (2001) menyarankan pentingnya karakteristik pekerjaan untuk engagement (Saks, 2006). Bahkan, karakteristik pekerjaan, terutama umpan balik dan otonomi, secara konsisten telah terbukti berkaitan dengan burnout (Saks, 2006). Berdasarkan perspektif SET, karyawan yang diberikan pekerjaan yang 
menantang akan merasa berkewajiban untuk merespon dengan tingkat engagement yang tinggi (Saks, 2006).

Kahn (1990) berpendapat bahwa karyawan berbeda-beda dalam engagement sebagai hasil dari persepsi tentang tunjangan yang diterima dari peran mereka. Berdasarkan perspektif SET, ketika karyawan menerima rewards dan pengakuan dari organisasi, maka mereka akan terpaksa merespon dengan tingkat engagement yang tinggi (Saks, 2006).

Salah satu faktor dalam organisasi yang dapat memengaruhi employee engagement adalah perceived organizational support (Sadeli, 2011). Karyawan yang menerima POS yang tinggi akan menjadi lebih engaged terhadap pekerjaan dan organisasi mereka sebagai wujud dari SET untuk membantu mencapai tujuan organisasi (Rhoades et al., 2001). Selain POS, PSS juga merupakan salah satu poin penting dari teori dukungan organisasi yang memengaruhi employee engagement (Saks, 2006). Kurangnya bentuk dukungan supervisor akan menjadi salah satu faktor penting yang memicu burnout (Saks, 2006).

Hipotesis penelitian ini adalah sebagai berikut : H1: Karakteristik pekerjaan positif berpengaruh terhadap engagement pekerjaan, H2: POS positif berpengaruh terhadap engagement pekerjaan, H3: PSS positif berpengaruh terhadap engagement pekerjaan, H4: Rewards dan pengakuan positif berpengaruh terhadap engagement pekerjaan, H5: Keadilan Prosedural positif berpengaruh terhadap engagement pekerjaan, H6: Keadilan Distributif positif berpengaruh terhadap engagement pekerjaan, H7: Karakteristik Pekerjaan positif berpengaruh terhadap engagement organisasi, H8: POS positif berpengaruh terhadap engagement organisasi, H9: PSS positif berpengaruh terhadap engagement organisasi, H10: Rewards dan pengakuan positif berpengaruh terhadap engagement organisasi, H11: Keadilan Prosedural positif berpengaruh terhadap engagement organisasi, H12: Keadilan
Distributif positif berpengaruh terhadap engagement organisasi.

Maslach et al. (2001) dalam engagement model yang dikembangkannya, menyatakan bahwa keadilan dan fairness merupakan salah satu kondisi kerja. Kurangnya keadilan yang dirasakan karyawan akan memperburuk burnout. Namun, bila keadilan dipersepsikan positif oleh karyawan maka hal tersebut akan meningkatkan engagement (Saks, 2006).

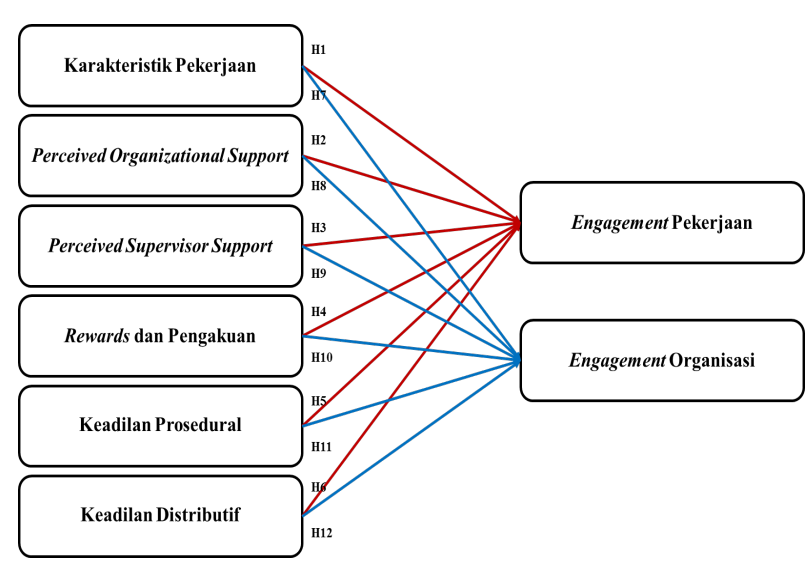

Gambar 1. Model Penelitian

Sumber: Saks (2006) dengan penyesuaian

\section{METODE}

Objek penelitian adalah Universitas X yang merupakan sebuah lembaga pendidikan tinggi dan berlokasi di Jakarta. Subjek penelitian adalah semua karyawan di Universitas X yang terdiri dari dosen tetap, staf, kordinator, supervisor, manajer, dan direktur. Pemilihan sektor pendidikan sebagai subjek penelitian terkait engagement dapat dibenarkan karena pada penelitiannya, Saks (2006) tidak memberikan syarat atau batasan tentang objek dan subjek yang tepat untuk dilibatkan dalam penelitian.

Pengambilan sampel probabilitas menggunakan teknik pengambilan acak sederhana (simple random sampling) yaitu tiap elemen populasi memiliki peluang yang sama dan diketahui untuk terpilih sebagai subjek (Sekaran, 2006:127). Penelitian ini akan melibatkan 110 karyawan. Responden Saks (2006) berasal dari karyawan dengan latar belakang pekerjaan yang beragam dan 
organisasi yang berbeda-beda, sementara itu penelitian ini akan melibatkan karyawan di sebuah organisasi (dalam hal ini Universitas $\mathrm{X})$ dengan jenis pekerjaan yang beragam. Selain itu, pada penelitiannya, responden Saks (2006) telah bekerja dengan pekerjaan yang ditekuni sekarang rata-rata 4 tahun, telah bergabung dengan organisasi rata-rata 5 tahun, dan dengan pengalaman kerja rata-rata 12 tahun. Sedangkan untuk penelitian ini, peneliti tidak mempertimbangkan lama karyawan dengan pekerjaan sekarang, lama bergabung dengan organisasi, dan pengalaman kerja. Peneliti melibatkan semua karyawan baik yang baru bergabung dengan Universitas X maupun yang telah lebih dari 9 tahun bekerja. Hal tersebut peneliti lakukan dengan pertimbangan bahwa populasi karyawan di Universitas X tidak besar (hanya 157 karyawan) sehingga bila peneliti mengikuti langkah Saks (2006) dengan hanya memilih karyawan yang berpengalaman di atas 4 tahun sebagai responden, maka jumlah populasi tentu akan berkurang. Data penelitian ini diperoleh melalui kuesioner dengan tipe terstruktur-tertutup, artinya semua pertanyaan yang diajukan kepada karyawan tertulis secara terperinci dalam kuesioner, ditanyakan langsung, dan setiap karyawan diberi kuesioner yang sama (Istijanto, 2006). Skala ini mengukur tingkat persetujuan atau ketidaksetujuan responden terhadap serangkaian pernyataan yang mengukur suatu objek dengan memberikan 5 atau 7 kategori dari "sangat setuju (SS)" sampai "sangat tidak setuju (STS)" (Istijanto, 2006; Sekaran, 2006).

\section{HASIL DAN PEMBAHASAN}

Responden penelitian ini terdiri dari 37 orang perempuan (46 persen) dan 44 orang laki-laki (54 persen). Usia responden terdiri dari 13 orang berusia antara 20,1-25 tahun (16 persen), 19 orang berusia antara 25,1-30 tahun (24 persen), 19 orang berusia antara 30,1-35 tahun (23 persen), dan 30 orang berusia lebih dari 35,1 tahun (37 persen). Tingkat pendidikan responden terdiri dari 15 orang dengan pendidikan terkahir SMA (18 persen), 4 orang bergelar D3 (5 persen), 7 orang bergelar S3 (9 persen), 16 orang bergelar S2 (20 persen), dan 39 orang bergelar S1 (48 persen).

Tabel 1: Nilai Komponen Matriks Semua Butir Pernyataan

\begin{tabular}{|c|c|c|}
\hline Variabel & $\begin{array}{c}\text { Butir } \\
\text { Pernyataan }\end{array}$ & Nilai Komponen Matriks \\
\hline \multirow[t]{5}{*}{ Karakteristik Pekerjaan } & $\mathrm{JC} 1$ & 0,764 \\
\hline & $\mathrm{JC} 3$ & 0,626 \\
\hline & JC4 & 0,641 \\
\hline & JC5 & 0,694 \\
\hline & JC6 & 0,742 \\
\hline \multirow[t]{8}{*}{ POS } & POS1 & 0,775 \\
\hline & POS2 & 0,828 \\
\hline & POS 3 & 0,679 \\
\hline & POS4 & 0,871 \\
\hline & POS5 & 0,745 \\
\hline & POS6 & 0,747 \\
\hline & POS7 & 0,665 \\
\hline & POS8 & 0,621 \\
\hline \multirow[t]{4}{*}{ PSS } & PSS1 & 0,805 \\
\hline & PSS2 & 0,797 \\
\hline & PSS3 & 0,855 \\
\hline & PSS4 & 0,708 \\
\hline \multirow[t]{10}{*}{ Rewards dan Pengakuan } & RR1 & 0,745 \\
\hline & RR2 & 0,650 \\
\hline & RR3 & 0,736 \\
\hline & RR4 & 0,779 \\
\hline & RR5 & 0,611 \\
\hline & RR6 & 0,792 \\
\hline & RR7 & 0,547 \\
\hline & RR8 & 0,540 \\
\hline & RR9 & 0,757 \\
\hline & RR10 & 0,715 \\
\hline \multirow[t]{4}{*}{ Keadilan Distributif } & DJ1 & 0,805 \\
\hline & DJ2 & 0,832 \\
\hline & DJ3 & 0,784 \\
\hline & DJ4 & 0,855 \\
\hline \multirow[t]{7}{*}{ Keadilan Prosedural } & PJ1 & 0,659 \\
\hline & $\mathrm{PJ} 2$ & 0,738 \\
\hline & PJ3 & 0,761 \\
\hline & PJ4 & 0,780 \\
\hline & PJ5 & 0,812 \\
\hline & PJ6 & 0,790 \\
\hline & PJ7 & 0,786 \\
\hline \multirow[t]{5}{*}{ Engagement Pekerjaan } & WE1 & 0,756 \\
\hline & WE2 & 0,685 \\
\hline & WE3 & 0,814 \\
\hline & WE4 & 0,627 \\
\hline & WE5 & 0,799 \\
\hline \multirow{6}{*}{ Engagement Organisasi } & OE1 & 0,798 \\
\hline & $\mathrm{OE} 2$ & 0,800 \\
\hline & $\mathrm{OE} 3$ & 0,714 \\
\hline & $\mathrm{OE} 4$ & 0,847 \\
\hline & OE5 & 0,894 \\
\hline & OE6 & 0,765 \\
\hline
\end{tabular}

Tabel 1, menunjukkan bahwa butir pernyataan pada masing-masing dimensi terdistribusi pada satu faktor yang terbentuk. Angka pada tabel (factor loading) menunjukkan besar korelasi antara indikator dengan faktor satu. Data tabel tersebut menggambarkan bahwa semua butir pernyataan pada semua dimensi memiliki angka korelasi yang tinggi. Hal tersebut dapat dilihat dari nilai factor loading yang berada di atas batas minimal yaitu 0,5 . Sehingga dapat dinyatakan hasil uji validitas semua variabel memiliki angka kelayakan tinggi sehingga 


\section{Published Volume 20 Nomor 2, Oktober, 2019, 134-145 \\ Jurnal Ilmiah Manajemen dan Bisnis \\ ISSN 1693-7619 (print) | ISSN 2580-4170 (online), http://jurnal.umsu.ac.id//index.php/mbisnis}

dapat dilanjutkan pada tahap pengujian selanjutnya. Kesimpulan uji validitas adalah semua dimensi dan indikator pernyataan memiliki korelasi yang tinggi dan valid. Uji reliabilitas terhadap semua variabel dilakuan menggunakan uji cronbach alpha dengan syarat minimal nilai alpha sebesar 0,6 . Hasil uji reliabilitas ditunjukkan dalam tabel di bawah ini. semua variabel memiliki nilai alpha rata-rata besar dari 0,7 sehingga telah memenuhi persyaratan reliabilitas variabel. Dapat disimpulkan bahwa semua variabel dalam penelitian ini sudah reliabel dan dapat digunakan untuk pengujian selanjutnya

Berdasarkan pengujian regresi linier berganda untuk menguji pengaruh anteseden terhadap engagement pekerjaan diperoleh hasil yang telah dirangkum sebagai berikut:

Tabel 3: Pengaruh Anteseden terhadap Engagement Pekerjaan

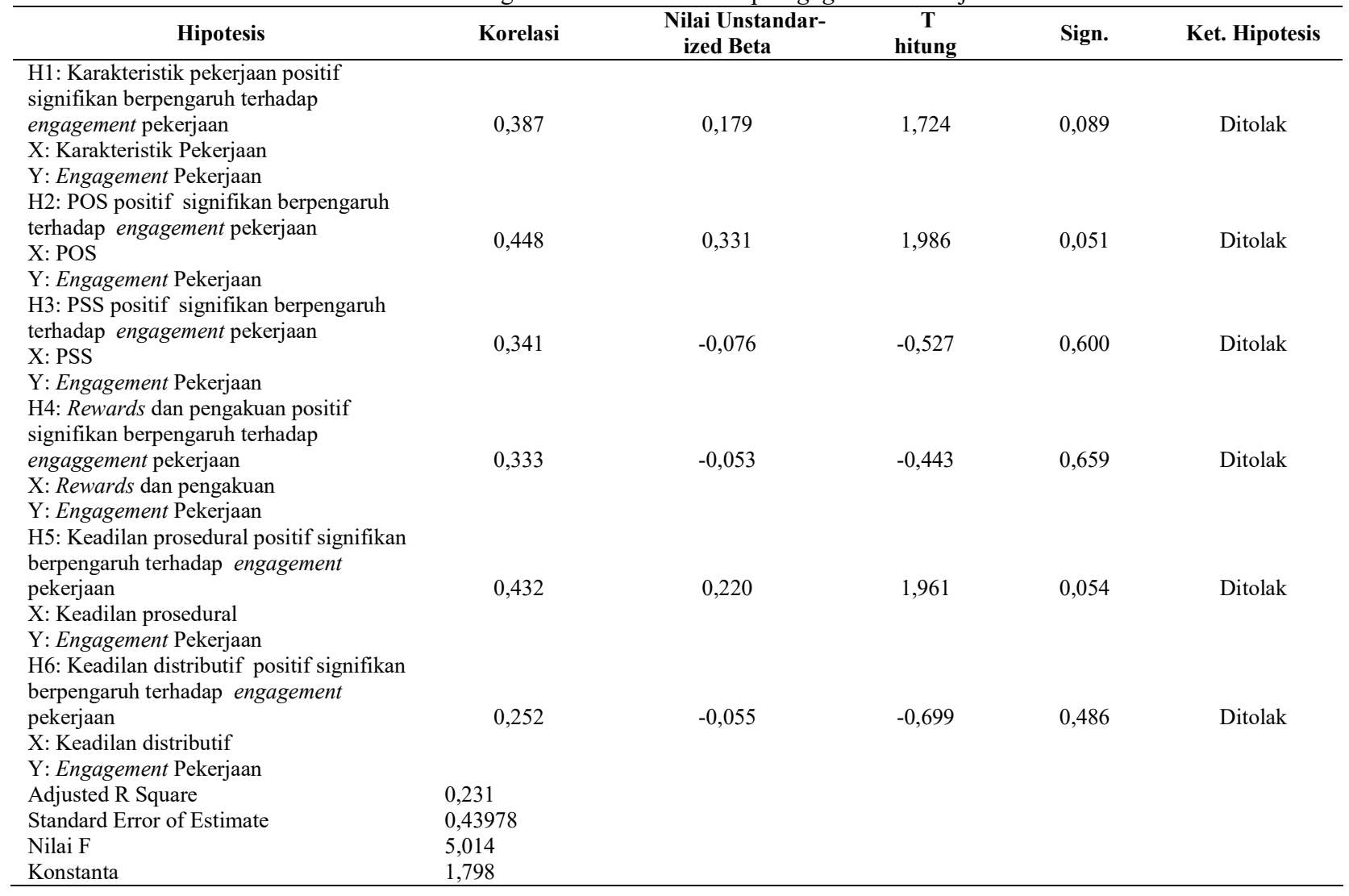

Berdasarkan hasil pengujian pada Tabel di atas, nilai adjusted $R$ square sebesar 23,1 persen menunjukkan korelasi ganda antara anteseden dengan engagement pekerjaan. Nilai adjusted $R$ square menunjukkan bahwa anteseden secara bersama-sama mampu menjelaskan engagement pekerjaan sebesar 23,1 persen.
Berdasarkan pengujian regresi linier berganda untuk menguji pengaruh anteseden terhadap engagement organisasi diperoleh hasil yang telah dirangkum sebagai berikut: 
Tabel 4. Pengaruh Anteseden terhadap Engagement Organisasi

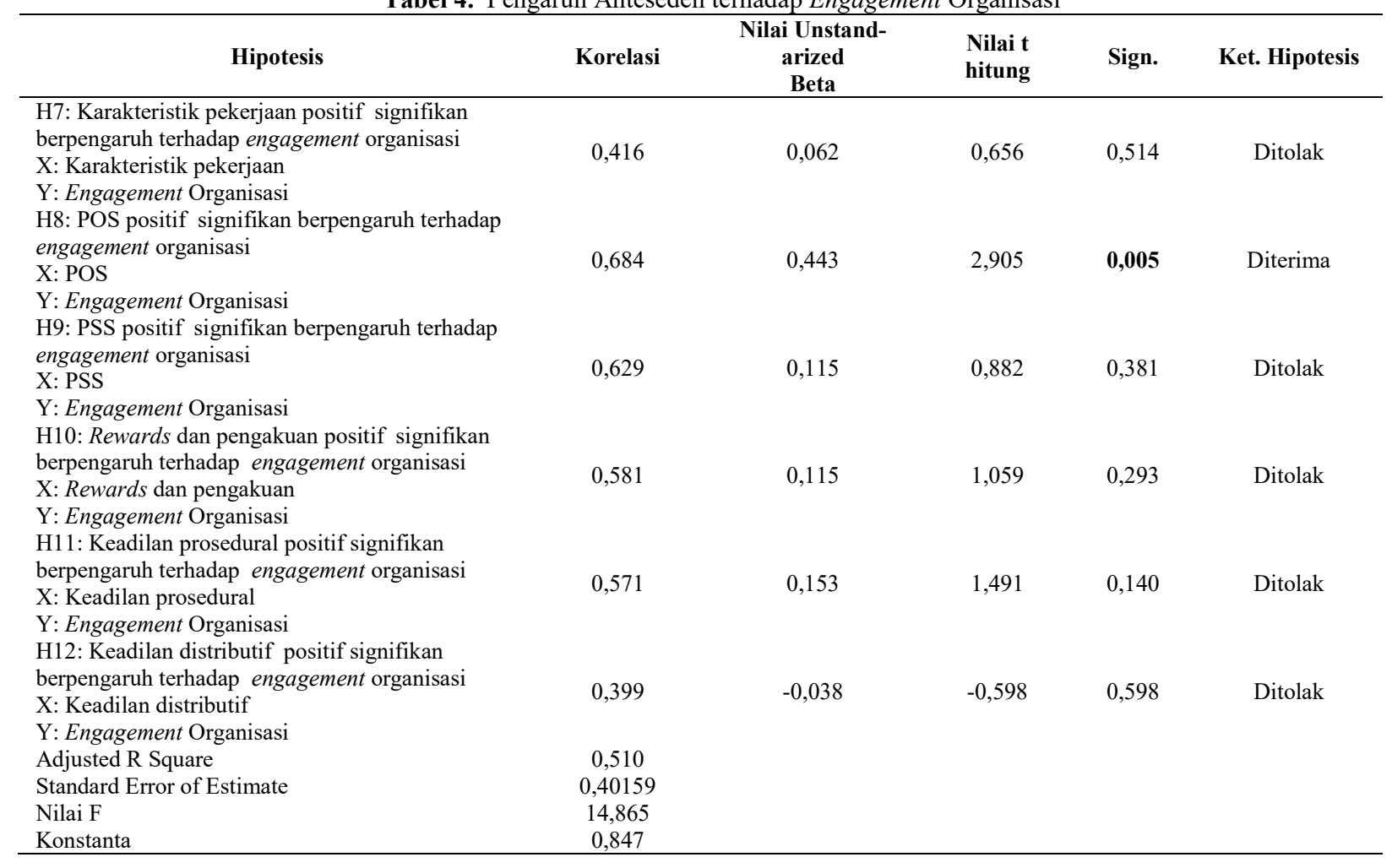

Berdasarkan hasil pengujian pada Tabel di atas, nilai adjusted $R$ square sebesar 51 persen menunjukkan korelasi ganda antara anteseden dengan engagement organisasi. Nilai adjusted $R$ square menunjukkan bahwa anteseden secara bersama-sama mampu menjelaskan engagement organisasi sebesar 51 persen. Sedangkan sisanya $(100 \%-$ $51 \%=49 \%$ ) dijelaskan oleh variabel lain yang tidak diteliti (lihat juga lampiran 17 tabel model summary). Variabel lain tersebut seperti: apresiasi, budaya organisasi, dan nilai-nilai yang dianut karyawan.

Besar hubungan antar variabel dalam anteseden dengan engagement organisasi dihitung menggunakan koefisien korelasi. Nilai koefisien korelasi antar variabel anteseden terhadap engagement organisasi adalah POS $(0,684)$, PSS $(0,629)$, rewards dan pengakuan $(0,581)$, keadilan prosedural $(0,571)$, karakteristik pekerjaan $(0,416)$, dan keadilan distributif $(0,399)$. Berdasarkan nilai koefisien korelasi dapat dinyatakan bahwa POS paling berpengaruh terhadap engaement pekerjaan bila dibandingkan variabel lain.

\section{Pembahasan}

Sebagai salah satu topik yang mendapat perhatian lebih dari praktisi bidang SDM, employee engagement penting untuk menjadi prioritas utama sebagai strategi perusahaan dalam rangka menciptakan keunggulan kompetitif perusahaan. Menciptakan employee engagement berarti mempersiapkan kekuatan SDM untuk menopang keberlanjutan organisasi. Sebagai sumbangsih dalam penelitian employee engagement, penelitian ini meneliti pengaruh sejumlah anteseden terhadap employee.

Menurut hasil perhitungan tingkat employee engagement dengan memperhatikan pembagian kategori engagement menurut Koscec (2007), karyawan Universitas X berada pada kategori engaged. Sehingga dapat dikatakan bahwa karyawan Universitas $\mathrm{X}$ secara emosional berkomitmen terhadap pekerjaan dan organisasi pada waktu yang seharusnya, mereka selalu menunjukkan pencapaian namun hanya sesekali memenuhi harapan. Hal tersebut berarti pencapaian 
karyawan Universitas $\mathrm{X}$ banyak yang tidak sesuai harapan.

Responden penelitian ini melibatkan semua level manajerial dan non-manajerial (dosen). Tingkat engagement pun ternyata memang bervariasi berdasarkan peran karyawan. Tingkat engagement tertinggi adalah para direktur dan dosen. Kondisi engagement level manajerial di Universitas X sudah bagus, hal tersebut bisa dilihat dari tingkat engagement para direktur, namun terjadi masalah pada level di bawah sehingga penting bagi para direktur untuk mendorong peningkatan engagement bawahan. Upaya tersebut didasarkan pada pandangan Wellins et al. (2005) yang menyatakan bahwa engagement harus dimulai dari manajemen puncak karena hanya satu dari empat pemimpin senior yang sangat engaged, sehingga tidak mungkin menjadikan karyawan engaged bila pemimpin disengaged. Pihak manajemen Universitas X harus meningkatkan apresiasi terhadap karyawan yang telah dikategorikan sebagai engaged.

Pembahasan tentang tingkat engagement karyawan Universitas $\mathrm{X}$ mengawali pembahasan utama tentang pengujian hipotesis penelitian ini. Berdasarkan penelitian terdahulu yang dilakukan oleh Saks (2006) ditemukan bahwa karakteristik pekerjaan signifikan memprediksi engagement pekerjaan, POS signifikan memprediksi engagement pekerjaan dan organisasi, dan PSS signifikan memprediksi engagement organisasi. Berdasarkan pengujian regresi linier berganda diperoleh hasil bahwa karakteristik pekerjaan tidak berpengaruh signifikan terhadap engagement pekerjaan, hasil ini tidak sama dengan penelitian Saks (2006) $(\rho<0,001)$ yang menemukan bahwa karakteristik pekerjaan positif signifikan berpengaruh terhadap engagement pekerjaan. Hasil penelitian selanjutnya menyatakan bahwa karakteristik pekerjaan tidak signifikan berpengaruh terhadap engagemnt organisasi.
Hasil pengujian tersebut menguatkan temuan Saks (2006).

Hasil pengujian di atas bertentangan dengan pandangan beberapa ahli. Kahn (1992) seperti yang dikutip Saks (2006) menyatakan bahwa karakteristik pekerjaan yang tinggi mendorong karyawan lebih engaged. Selain itu, temuan ini juga bertentangan dengan Maslach et al. (2001) yang menyarankan pentingnya karakteristik pekerjaan terhadap engagement. Kedua ahli tersebut tidak menjelaskan lebih lanjut apakah engagement pekerjaan atau organisasi karena kedua peneliti tersebut meneliti sebelum tahun penelitian Saks (2006) dimana pada saat tersebut para peneliti engagement belum melakukan pembedaan antara konstruk engagement pekerjaan dengan engagement organisasi.

Tingkat karakteristik pekerjaan karyawan Universitas X sebesar 65,93 persen. Hasil tersebut dapat diartikan bahwa karyawan Universitas X merasa bahwa variasi keterampilan, nilai penting tugas, identitas tugas, otonomi, dan umpan balik yang mereka terima sudah cukup. Bila dibandingkan dengan tingkat engagement pekerjaan sebesar 73,23 persen dan engagement organisasi sebesar 74,03 persen, seharusnya tingkat karakteristik pekerjaan dapat memengaruhi engagement pekerjaan dan organisasi. Hasil tersebut tidak sejalan dengan pandangan Kahn (1992) bahwa karyawan dengan karakteristik pekerjaan yang tinggi mengarahkan mereka menjadi lebih engaged (Saks, 2006). Peneliti tidak menyarankan karakteristik pekerjaan untuk engagement seperti yang disarankan (Saks, 2006) mengingat hasil penelitian ini menunjukkan karakteristik pekerjaan tidak berpengaruh terhadap engagement pekerjaan dan organisasi. Bila dipandang menggunakan perspektif SET, tingkat karakteristik pekerjaan dan organisasi karyawan Universitas $\mathrm{X}$ yang cukup tinggi dapat mendorong karyawan untuk merespon dengan tingkat engagement yang tinggi seperti yang diungkapkan Saks (2006). 


\section{Jurnal Ilmiah Manajemen dan Bisnis}

Lebih lanjut, berdasarkan perspektif SET, dapat dijelaskan bahwa tidak berpengaruhnya karakteristik pekerjan terhadap engagement mungkin disebabkan oleh salah satu pihak (bisa atasan atau bawahan) tidak mematuhi aturan pertukaran dalam hubungan ketergantungan satu sama lain engagement (dalam hal ini Saks tidak menjelaskan apakah yang dimaksud adalah engagement pekerjaan atau organisasi). Aturan pertukaran tersebut menurut Saks (2006) adalah tindakan salah satu pihak tidak memengaruhi pihak lain atau tindakan tersebut tidak mendapat respon dari pihak lain. Menurut Robinson et al. (2004) engagement merupakan hubungan dua arah antara atasan dan bawahan. Hal tersebut dapat dimaknai bahwa pada kasus di Universitas X, bisa jadi otonomi, identitas tugas, keanekaragaman keterampilan, arti tugas, dan umpan balik tidak membentuk hubungan dua arah dan respon yang dihasilkan tidak memengaruhi pihak lain.

Hasil bahwa kerakteristik pekerjaan yang tidak signifikan berpengaruh terhadap engagement yang menjelaskan bahwa karyawan Universitas X berbeda-beda memandang engagement. Karyawan berdasarkan jabatan yang memiliki karakteristik pekerjaan yang tinggi belum tentu memiliki engagement yang tinggi pula terhadap pekerjaan dan organisasi. Sebagai contoh, para manajer memiliki tingkat karakteristik pekerjaan sebesar 66,4 persen, namun memiliki tingkat engagement pekerjaan sebesar 76 persen dan organisasi sebesar 77,33 persen. Para dosen memiliki karakteristik pekerjaan sebesar 73 persen memiliki tingkat engagement pekerjaan ( 73,75 persen) dan organisasi ( 76,87 persen). Bila dibandingkan, manajer dengan karakteristik pekerjaan yang lebih kecil justru memiliki tingkat engagement yang lebih tinggi dibandingkan para dosen yang memiliki tingkat karakteristik pekerjaan yang lebih besar, namun memiliki engagement yang lebih rendah. Jadi, tingkat karakteristik pekerjaan tidak memengaruhi tinggi atau rendahnya engagement karyawan di Universitas X.

Berdasarkan pengujian regresi linier berganda diperoleh hasil bahwa POS tidak berpengaruh signifikan terhadap engagement pekerjaan. Hasil tersebut tidak sama dengan penelitian Saks $(2006) \quad(\rho<0,01) \quad$ yang menemukan bahwa POS positif signifikan berpengaruh terhadap engagement pekerjaan. Meskipun nilai signifikansi POS sebesar 0,051 dapat dikatakan berpengaruh bila taraf kepercayaan diturunkan dari 95 persen menjadi 90 persen, seperti yang dilakukan Saks (2006) pada beberapa variabel dalam penelitiannya, namun penelitian ini konsisten menggunakan taraf kepercayaan 95 persen (signifikansi minimal 0,05 ). Hasil penelitian selanjutnya menyatakan bahwa POS positif signifikan berpengaruh terhadap engagement organisasi. Hasil pengujian tersebut menguatkan temuan Saks (2006).

Hasil pengujian dapat dikatakan sejalan dengan perbedaan tingkat POS dan engagement pekerjaan dan organisasi berdasarkan jabatan karyawan Universitas X. Pada pengujian, signifikansi POS terhadap engagement pekerjaan hampir dapat dikatakan berpengaruh karena nilai signifikansi 0,051. Nilai POS karyawan berdasarkan jabatan, beberapa karyawan memiliki tingkat POS yang tinggi namun engagement pekerjaannya rendah. Misal, supervisor dan kordinator masing-masing tingkat POS sebesar 74,38 persen dan 76,56 persen, namun memiliki engagement pekerjaan sebesar 71 persen dan 67,33 persen. Hasil tersebut berbanding terbalik dengan jabatan lain, misal direktur dan staf yang menggambarkan semakin tinggi tingkat POS maka tingkat engagement pekerjaan juga tinggi.

Tingkat engagement organisasi karyawan Universitas X berdasarkan jabatan konsisten dengan tingkat POS, semakin tinggi POS maka semakin tinggi pula engagement organisasi. Hal tersebut mendukung hasil pengujian bahwa POS signifikan berpengaruh terhadap engagement organisasi. Hasil 


\section{Published Volume 20 Nomor 2, Oktober, 2019, 134-145 \\ Jurnal Ilmiah Manajemen dan Bisnis}

ISSN 1693-7619 (print) | ISSN 2580-4170 (online), http://jurnal.umsu.ac.id/index.php/mbisnis

pengujian pengaruh POS terhadap engagement pekerjaan dan organisasi sesuai dengan pernyataan Sadeli, (2011) dan Saks, (2006) yang menyatakan bahwa semakin tinggi POS maka tingkat engagement juga semakin tinggi. Pengaruh tersebut menjadi wujud SET untuk membantu mencapai tujuan organisasi seperti yang dikemukakan oleh Rhoades et al. (2001).

POS yang diterima oleh karyawan akan menciptakan kepercayaan karyawan terhadap organisasi sehingga karyawan akan engaged terhadap organisasi. Bila POS menurun, maka engagement terhadap organisasi juga akan menurun. Hal tersebut berdampak menurunnya kepercayaan karyawan terhadap universitas $\mathrm{X}$ sebagaimana yang diungkapkan Eisenberger dan kolega (Eisenberger, Fasolo, dan Davis-LaMastro, 1990) bahwa POS diciptakan untuk menggambarkan kepercayaan karyawan tentang sejauh mana organisasi menghargai kontribusi dan peduli terhadap kesejahteraan karyawan.

Berdasarkan pengujian regresi linier berganda diperoleh hasil bahwa PSS tidak berpengaruh signifikan terhadap engagement pekerjaan dan organisasi Hasil pengujian tersebut menguatkan temuan Saks (2006). PSS tidak berpengaruh terhadap engagement pekerjaan karena mayoritas responden adalah dosen, pada dasarnya dosen tidak memiliki atasan langsung sehingga ada atau tidak dukungan dari atasan mereka, para dosen akan tetap engaged terhadap pekerjaan sebagai pengajar. PSS tidak berpengaruh pula terhadap engagement organisasi karena ada atau tidaknya PSS, para dosen akan tetap engaged terhadap organisasi. Kondisi tidak berpengaruhnya PSS terhadap engagement pekerjaan dan organisasi mungkin disebabkan karena PSS merupakan anteseden terkuat POS sehingga untuk membuat pengaruh yang signifikan dibutuhkan peran POS sebagai variabel mediator, tentunya perlu dilakukan penelitian lebih lanjut terkait isu tersebut.

Berdasarkan pengujian regresi linier berganda diperoleh hasil rewards dan pengakuan tidak berpengaruh signifikan terhadap engagement pekerjaan dan organisasi. Hasil pengujian tersebut menguatkan temuan Saks (2006) dan Wulandari dan Gustomo, (2012). Rewards dan pengakuan tidak berpengaruh terhadap engagement karena besar atau kecil rewards yang diterima oleh karyawan bukan faktor untuk menjadi engaged, menurut Ardianto, (2009) seseorang menerima rewards pada akhirnya akan menjadi berkomitmen setelah dimediasi oleh POS. Pendapat ini menguatkan hasil regresi bahwa rewards dan pengakuan tidak berpengaruh terhadap engagement karena mayoritas responden adalah dosen sehingga kompensasi bukan merupakan satu-satunya motivasi untuk engaged. Kenyataan ini juga dipertegas bahwa tingkat engagement pada setiap karakteristik individu akan berbeda-beda. Hal ini sejalan dengan Wulandari dan Gustomo (2012) yang menyatakan bahwa kompensasi bukan merupakan satu-satunya motivator seseorang untuk engaged, karyawan bekerja lebih dari sekedar untuk mendapatkan uang. Meskipun kompensasi memiliki potensi sebagai engaged faktor yang kuat, tingkat efektifitasnya mungkin dipengaruhi situasi dan karakteristik individu yang beragam.

Tingkat rewards dan pengakuan karyawan Universitas X sebesar 58,59 persen, hal tersebut berarti sekitar 58,59 persen karyawan menyatakan bahwa rewards dan pengakuan yang mereka terima sudah sesuai. Sekitar 41,41 persen karyawan menyatakan bahwa rewards dan pengakuan yang mereka terima belum sesuai. Perbandingan karyawan yang menyatakan sesuai dengan tidak sesuai hampir sama besar. Sesuai dengan pernyataan Saks (2006) berdasarkan perspektif SET, bahwa karyawan yang menerima rewards dan pengakuan yang besar dari organisasi, cenderung akan merespon dengan tingkat engagement yang tinggi pula. Bila dihubungkan dengan perbandingan rewards dan pengakuan yang diterima karyawan Universitas X terhadap tingkat engagement, maka pernyataan Saks (2006) terbantahkan. Hal tersebut bisa dilihat dengan 


\section{Jurnal Ilmiah Manajemen dan Bisnis}

ISSN 1693-7619 (print) | ISSN 2580-4170 (online), http://jurnal.umsu.ac.id/index.php/mbisnis

membandingkan antara rewards dan pengakuan yang diterima karyawan Universitas $\mathrm{X}$ yang hampir berada digaris rata-rata/hampir cukup sesuai tidak sejalan dengan tingkat engagement karyawan yang tinggi. Hal tersebut mungkin mendorongan tidak signifikannya rewards dan pengakuan terhadap engagement karyawan Universitas $\mathrm{X}$ terhadap pekerjaan dan organisasi.

Hasil penelitian juga menjelaskan bahwa rata-rata direktur beranggapan bahwa rewards dan pengakuan yang mereka terima sudah sesuai (73,75 persen), bandingkan dengan tingkat engagement pekerjaan (88 persen) dan organisasi (91,66 persen). Data pada Gambar 4.7 memperlihatkan bahwa semakin kecil rewards dan pengakuan yang diterima karyawan Universitas $\mathrm{X}$ maka tingkat engagement mereka terhadap pekerjaan dan organisasi juga cenderung menurun.

Berdasarkan pengujian regresi linier berganda diperoleh hasil bahwa keadilan prosedural tidak berpengaruh signifikan terhadap engagement pekerjaan. Hasil tersebut menguatkan hasil penelitian Saks (2006). Pengaruh keadilan prosedural pada penelitian ini berbeda dengan Saks (2006) karena perbedaan penggunaan taraf kepercayaan. Saks (2006) menggunakan taraf kepercayaan 90 persen sedangkan penelitian ini menggunakan taraf kepercayaan 95 persen. Bila taraf penelitian ini diturunkan menjadi 90 persen seperti yang dilakukan Saks (2006), maka keadilan prosedural signifikan berpengaruh terhadap engagement pekerjaan karena nilai signifikansinya sebesar 0,054. Hasil penelitian selanjutnya menyatakan bahwa keadilan prosedural tidak signifikan berpengaruh terhadap engagement organisasi. Hasil tersebut bertentangan dengan temuan Saks $(2006)(\rho<0,10)$ yang menyatakan bahwa keadilan prosedural positif signifikan berpengaruh terhadap engagement organisasi.

Penelitian ini juga menunjukkan tingkat keadilan prosedural berdasarkan jabatan, secara umum menyatakan bahwa semakin tinggi keadilan prosedural yang diterima karyawan Universitas X, maka engagement pekerjaan dan organisasi juga tinggi. Hal tersebut sesuai dengan pernyataan Saks (2006) bahwa bila keadilan dipersepsikan positif oleh karyawan maka hal tersebut akan meningkatkan engagement. Tingkat keadilan prosedural setiap jabatan menunjukkan peningkatan pula pada engagement pekerjaan dan organisasi. Namun, berdasarkan pengujian regresi linier berganda, keadilan prosedural tidak signifikan berpengaruh terhadap engagement pekerjaan dan organisasi.

Kondisi tidak berpengaruhnya PSS, rewards, pengakuan, dan keadilan prosedural terhadap engagement dapat dijelaskan melalui hasil meta analisis yang dilakukan oleh Rhoades dan Eisenberger (Aselage dan Eisenberger, 2003). Studi tersebut menjelaskan bahwa terdapat tiga anteseden POS yaitu, penghargaan organisasi, PSS, dan keadilan prosedural. Sehingga ketiga variabel tersebut lebih tepat memprediksi POS dibanding engagement.

Berdasarkan pengujian regresi linier berganda diperoleh hasil bahwa keadilan distributif tidak berpengaruh signifikan terhadap engagement pekerjaan dan organisasi. Hasil tersebut menguatkan hasil penelitian Saks (2006). Kenaikan pada tingkat keadilan distributif setiap jabatan menunjukkan peningkatan pula pada engagement pekerjaan dan organisasi. Namun, perbedaan tingkat keadilan distributif terhadap engagement pekerjaan dan organisasi terlalu jauh sehingga berpengaruh terhadap tidak signifikannya pengaruh keadilan distributif terhadap engagement pekerjaan dan organisasi. Hal tersebut sejalan dengan pandangan Saks (2006) bahwa bila karyawan menilai positif keadilan, maka tingkat engagement juga akan tinggi.

\section{SIMPULAN}

Setelah melakukan pembahasan pada penelitian ini, dapat ditarik kesimpulan sebagai berikut. Berdasarkan pengujian 
regresi berganda, karakteristik pekerjaan tidak berpengaruh terhadap engagement pekerjaan; POS tidak berpengaruh terhadap engagement pekerjaan; PSS tidak berpengaruh terhadap engagement pekerjaan; rewards dan pengakuan tidak berpengaruh terhadap engagement pekerjaan; keadilan prosedural tidak berpengaruh terhadap engagement pekerjaan; keadilan distributif tidak berpengaruh terhadap engagement pekerjaan; karakteristik pekerjaan tidak berpengaruh terhadap engagement organisasi; POS positif signifikan berpengaruh terhadap dan engagement organisasi; PSS tidak berpengaruh terhadap engagement organisasi; rewards dan pengakuan tidak berpengaruh terhadap engagement organisasi; keadilan prosedural tidak berpengaruh terhadap engagement organisasi; keadilan distributif tidak berpengaruh terhadap engagement organisasi.

Penelitian selanjutnya dapat mempertimbangkan meneliti tentang hubungan variabel lain terhadap employee engagement. Variabel-variabel yang dimaksud dapat merupakan kajian lama misalnya rekrutmen atau kajian baru seperti manajemen talenta atau variabel-variabel yang memengaruhi engagement pekerjaan dan organisasi namun tidak diteliti dalam penelitian ini. Variabel-variabel tersebut antara lain: kinerja dan produktivitas, turnover dan return on investment, ketidakpuasan pelanggan, dan apresiasi.

Beberapa variabel yang dapat diteliti pada penelitian selanjutnya antara lain: Kepemimpinan, Peneliti menyarankan peneliti selanjutnya dapat mengkaji tentang pengaruh kepemimpinan terhadap employee engagement, khususnya kepemimpinan. Variabel kepemimpinan sangat penting untuk diteliti karena menurut Wellins et al. (2005) engagement harus dimulai dari manajemen puncak karena hanya satu dari empat pemimpin senior yang sangat engaged, sehingga tidak mungkin menjadikan karyawan engaged bila pemimpin disengaged. Budaya organisasi sangat peneliti sarankan karena asumsi peneliti bahwa pengaruh engagement organisasi terhadap sejumlah konsekuensi mungkin dipengaruhi karena kultur yang dibangun pendiri utama Universitas X yang karakternya sangat kuat tidak hanya bagi universitas tersebut tetapi juga terhadap negara. Kinerja, Peneliti menyarankan agar peneliti selanjutnya dapat mengelaborasi pengaruh engagement terhadap kinerja karyawan, dosen, dan mahasiswa serta hasil (keluaran universitas) seperti IPK mahasiswa, karya cipta, penelitian, dan lain sebagainya. Terkait mahasiswa, penelitian lanjutan dapat menggunakan istilah student engagement yang telah populer digunakan oleh beberapa penelitian terdahulu. Jenis Kelamin, Penelitian selanjutnya diharapkan meneliti lebih lanjut tentang hubungan dan perbedaan demografi responden terhadap employee engagement, misalnya hubungan jenis kelamin, jabatan, dan lama bekerja terhadap engagement pekerjaan dan organisasi. Berdasarkan hasil penelitian ini, tingkat engagement pekerjaan laki-laki adalah 73,36 persen lebih besar dari perempuan 73,08 persen. Sedangkan perempuan lebih terikat terhadap organisasi dibanding laki-laki. Penelitian selanjutnya diharapkan dapat menjawab sejumlah pertanyaan terkait perbedaan tersebut, misalnya mengapa lakilaki lebih engaged terhadap pekerjaan, sementara perempuan lebih engaged terhadap organisasi?. Perbandingan hasil tersebut dengan sejumlah penelitian pada organisasi sejenis tentu akan menjadi diskusi menarik terutama dalam menjawab apakah fenomena tersebut berlaku pada kebanyakan institusi pendidikan ataukah memang terjadi kekhususan terhadap organisasi di Universitas X. Jabatan, Penelitian ini memberikan gambaran bahwa tingkat engagement berbeda-beda berdasarkan jabatan karyawan Universitas X. Pada penelitian ini ada lima jabatan yang dikategorikan yaitu dosen tetap, staf, kordinator, supervisor, manajer, dan direktur. Hasil penelitian menunjukkan bahwa direktur memiliki nilai terbaik disemua 


\section{Jurnal Ilmiah Manajemen dan Bisnis}

ISSN 1693-7619 (print) | ISSN 2580-4170 (online), http://jurnal.umsu.ac.id/index.php/mbisnis

variabel yang diteliti. Hal tersebut juga berlaku untuk para dosen tetap. Namun, yang menjadi permasalahan serius di Universitas $X$ adalah rendahnya penilaian para staf dan kordinator terhadap semua variabel dalam penelitian ini, bahkan pada beberapa variabel perbedaan nilai tingkatan cukup jauh dibanding jabatan lain. Penelitian selanjutnya diharapkan dapat meneliti dampak gap yang cukup besar pada beberapa variabel terutama variabel-variabel yang signifikan berpengaruh pada penelitian ini, Lama Bekerja, Hasil penelitian ini menggambarkan bahwa karyawan di Universitas $\mathrm{X}$ akan mencapai tingkat engagement optimal pada usia kerja 7,1-9 tahun. Namun, karyawan yang telah bekerja lebih dari 9 tahun tingkat engagement akan hampir sama dengan karyawan yang usia kerjanya $\leq 1$ tahun. Bila dilihat, hal tersebut seperti membentuk piramida, dimulai dari kurang engaged bergerak menjadi sangat engaged kemudian menurun lagi seperti semula. Temuan tersebut sanat menarik terutama bila diperhatikan lanjut terhadap jumlah responden, kondisi ini berbahaya karena jumlah karyawan masa kerja besar dari 9 tahun adalah yang terbanyak yaitu 22 orang. Selain itu, karyawan usia 1,1-3 tahun memiliki jumlah responden kedua terbanyak dan memiliki tingkat engagement organisasi nomor 2 terendah. Hal ini kaitannya dengan pengaruh engagement organisasi terhadap sejumlah outcomes. Fakta lain, bahwa selain masa kerja besar dari 9 tahun, kondisi kerja 3,1-5 tahun memiliki tingkat engagement pekerjaan yang rendah dengan jumlah responden terbanyak ketiga.

Beberapa saran yang dapat peneliti berikan untuk diimplementasikan oleh manajemen di Universitas $\mathrm{X}$ adalah sebagai berikut: Apresiasi Disengagement, Karyawan yang telah engaged sangat perlu untuk beberapa waktu melepaskan diri dari pekerjaan. Universitas $\mathrm{X}$ harus bisa memprogramkan berbagai kebijakan terkait pemberian istirahat atau cuti dalam jangka waktu yang cukup untuk melepaskan karyawan dari pekerjaan mereka sejenak.
Pihak Universitas harus mampu mengidentifikasi kapan waktu yang tepat bagi para karyawan untuk dilepaskan sejenak dari rutinitas pekerjaan. Peneliti menyarankan waktu yang tepat misalnya saat karyawan telah selesai melaksanakan tugas yang berat atau sebuah proyek yang memberikan pengaruh besar bagi Universitas. Selain itu, bisa juga diberikan ketika kinerja karyawan menurun disebabkan oleh beban kerja yang telah diterima dalam satu kurun waktu tertentu. Kebijakan disengaged bagi karyawan diharapkan menjadi bentuk apresiasi atau rewards atas kontribusi karyawan terhadap kemajuan Universitas. Peneliti menyarankan agar pihak manajemen mengkomunikasikan kebijakan disengaged kepada karyawan dengan baik. Pihak manajemen tidak boleh memberikan pemahaman bahwa kebijakan tersebut sebagai sebuah hukuman agar tidak terbentuk persepsi negatif yang nantinya akan dianggap sebagai tindakan ketidakpedulian organisasi terhadap karyawan. Bila hal persepsi negatif tersebut terbentuk, maka akan memperburuk persepsi penerimaan karyawan (POS rendah) yang nantinya justru memperburuk tingkat engagement orgnanisasi yang pada akhirnya berdampak terhadap menurunnya kepuasan kerja, komitmen organisasi, dan meningkatnya intention to quit. Menciptakan Engagement dari Proses Rekrutmen dan Seleksi, Bila ingin mewujudkan employee engagement, universitas $\mathrm{X}$ harus memulai sejak proses rekrutmen dengan mempertimbangkan karakteristik calon karyawan. Karyawan baru yang diterima harus memiliki visi dan tujuan yang sejalan dengan organisasi dan pekerjaan mereka nanti agar tercipta loyalitas dan komitmen organisasi dan menurunnya intention to quit. Peneliti menekankan pada pentingnya para calon karyawan mengikuti visi, misi, dan nilai-nilai organisasi, bukan organisasi yang harus berkompromi terhadap tujuan dan nilainilai yang dianut oleh karyawan. Hal tersebut sangat penting karena pada hakikatnya sebuah organisasi adalah tempat para karyawan 
mencapai tujuan yang sama. Para manajemen puncak telah merumuskan target-target yang akan dicapai dan diwujudkan secara bersama oleh para karyawan. Namun, bila organisasi berkompromi dengan karyawan yang pada hakikatnya memiliki kepentingan dan tujuan berbeda-beda maka arah organisasi menjadi tidak jelas. Peneliti menekankan penciptaan engagement sejak proses rekrutmen dan seleksi adalah untuk menurunkan biaya pelatihan dan pengembangan bagi karyawan agar diarahkan menjadi engaged. Pada kondisi ini, peran departemen SDM menjadi sangat penting. Departemen SDM harus mampu menemukan cara terbaik dalam mewujudkan sistem rekrutmen dan seleksi yang berkualitas. Hal tersebut tentu juga harus dikomunikasikan dengan para user agar tercipta kesepahaman tentang calon karyawan yang tidak sekedar dibutuhkan tetapi juga sesuai dengan arah pengembangan organisasi.

\section{Engagement}

Berkelanjutan,

Engagement harus dilaksanakan dan dikembangkan untuk jangka pendek dan panjang secara berkelanjutan karena engagement merupakan konsep yang mudah namun sulit untuk dieksekusi. Sehingga penting bagi level manajerial untuk dapat merumuskan upaya menciptakan engagement secara berkelanjutan dengan kontrol yang baik. Keberlanjutan engagement di Universitas $\mathrm{X}$ ditujukan untuk mencapai keunggulan kompetitif dalam rangka mewujudkan visi Universitas X. Tingkat employee engagement di Universitas X sudah dikategorikan engaged, hal tersebut akan berdampak pada kinerja karyawan Universitas X. Meski sudah dikategorikan engaged, pihak manajemen harus berupaya meningkatkan engagement mengingat kategori engaged belum berdampak baik bagi Universitas X. Karyawan dalam kategori engaged memang mampu menyelesaikan pekerjaan dan tanggung jawabnya, namun hal tersebut hanya untuk sekedar menyelesaikan tuntutan tugas, tidak untuk memberikan nilai lebih bagi keunggulan Universitas $\mathrm{X}$. Mempertahankan dan Meningkatkan POS, terkait hasil penelitian ini, peneliti menyarankan agar pihak manajemen Universitas $\mathrm{X}$ untuk terus meningkatkan dukungan organisasi terhadap karyawan agar karyawan semakin engaged terhadap universitas. Hal tersebut perlu dilakukan untuk meningkatkan kepuasan kerja dan menurunkan intention to quit karyawan. Bila pihak manajemen dapat menurunkan intention to quit, maka biaya untuk proses rekrutmen dan seleksi serta pelatihan dan pengembangan dapat dikelola dengan baik.

Penelitian ini pada awalnya diharapkan dapat melibatkan semua karyawan di Universitas X dengan metode sensus. Hal tersebut bertujuan untuk meningkatkan keakuratan hasil penelitian serta secara tepat dapat mengukur perbedaan tiap karakteristik responden. Sehingga perbandingannya pun dapat dijelaskan dengan tingkat kesalahan yang relatif lebih kecil. Namun, pada proses penyebaran kuesioner, terdapat kendala berupa keengganan responden mengisi kuesioner dengan berbagai alasan seperti sedang sibuk bekerja, dateline pekerjaan, menunda mengisi, dan lupa. Selain itu, tenggat waktu pengisian kuesioner tidak sejalan dengan kedudukan para responden di lingkungan kerja sehingga mengharuskan peneliti mengambil sampel secara acak sederhana.

\section{REFERENSI}

Ardianto, Andika. (2009). Perceived Organizational Support Sebagai Pemediasi Pengaruh Keadilan Prosedural, Penghargaan, dan Dukungan Supervisor Terhadap Komitmen Afektif. Surakarta: Skripsi di Universitas Sebelas Maret.

Ali, R, and M. Shakil Ahmed. (2009). The Impact of Reward and Recognition Programs on Employee's Motivation and Satisfaction: An Empirical Study. International Review of Business Research Papers, 5(4), 270-79. 


\section{Published Volume 20 Nomor 2, Oktober, 2019, 134-145 \\ Jurnal Ilmiah Manajemen dan Bisnis}

ISSN 1693-7619 (print) | ISSN 2580-4170 (online), http://jurnal.umsu.ac.id/index.php/mbisnis

Andaleeb, Sultan Saad. (2006). A Relational Study on Perceived Organizational Support, Supervisory Support, Work Climate, and Employee Service Quality in the Context of British American Tobacco Bangladesh. Bangladesh: Laporan Magang di Independent University.

Aselage, Justin dan Robert Eisenberger. (2003). "Perceived Organizational Support and Psychological Contracts: a Theoretical Integration". Journal of Organizational Behavior. 24, 491509.

Chiang, Flora F.T. and Thomas A. Birtch. (2012). The Performance Implications of Financial and Nonfinancial Rewards: An Asian Nordic Comparison. Journal of Managemetn Studies, 49(3), 53870.

Cole, Michael S., Heiki Bruch, and Bernd Vogel. (2006). Emotion as Mediators of the Relations between Perceived Supervisor Support and Psychological Hardiness on Employee Cynicism. Journal of Organizational Behaviour, 27, 463-84.

Djastuti, I. (2011). Pengaruh Karakteristik Pekerjaan Terhadap Komitmen Organisasi Karyawan Tingkat Managerial Perusahaan Jasa Konstruksi Di Jawa Tengah. Jurnal Bisnis dan Akuntansi, 13 (1), 1-19.

Eisenberger, Robert, Peter Fasolo, and Valerie Davis-LaMastro. (1990). Perceived Organizational Support and Employee Diligence, Commitment, and Innovation. Journal of Applied Psychology, 75(1). 51-59.

Eisenberger, Robert, Ivan L. Sucharski and Linda Rhoades, and Florence Stinglhamber and Christian Valdenberghe. (2002). Perceived Supervisor Support: Contributions to Perceived Organizational Support and Employee Retention. Journal of Applied Psychology, 87(3). 565-73.

Mustafa, Eq Zainal. (2008). Pengaruh Keadilan Distributif dan Prosedural Terhadap Kesejahteraan dan Kepuasan Kerja Serta Keinginan Mogok Kerja Karyawan Industri Tekstil di Eks Kresidenan Surakarta. Majalah Ekonomi. Tahun XVIII, No. 2.

Faturrochman. (2002). Keterikatan antara Anteseden, Penilaian Keadilan Prosedural, Penilaian Keadilan Distributif, dan Dampaknya. Yogyakarta: Disertasi di Universitas Gadjah Mada.

Firman. (2011). Pengaruh Karakteristik Pekerjaan terhadap Kepuasan Kerja Pegawai di Lingkungan Pemkot Payakumbuh. Tingkap, 7(2).

Frimansah, Moh. Irsan dan Raeny Dwi Santy. (2011). Pengaruh Iklim Organisasi dan Karakteristik Pekerjaan Terhadap Kepuasan Kerja Pegawai di Lingkungan Pemerintahan Dearah Kabupaten Sukabumi". Majalah Ilmiah Unikom, 6(2).

Foong-ming, Tan. (2008). Lingking Career Development Practices to Turnover Intention: The Mediator of Perceived Organizational Support". Journal of Business and Public Affair. 2(1), 1-20.

Global Talent 2021. (2012). Oxford Economics.

Global Workforce Study 2012. (2012). Tower Watson.

Gruman, Jamie A. dan Alan M. Saks. (2011). Performance and Employee Engagement. Human Management Review, 21. 123-36.

Gunastri, Ni Made. (2009). Karakteristik Individu, Karakteristik Pekerjaan, Karakteristik Organisasi, Motivasi Kerja, dan Kinerja Karyawan: 
Studi Pada CV Kecak Denpasar. Forum Manajemen, 7(1).

Handi S., Suminar dan Fendy Suhariandi. (2009). Pengaruh Persepsi Karyawan tentang Keadilan Organisasi terhadap Intensi Turnover di PT. ENG Gresik.

Hartawan, Aleksander. (2003). Hubungan Karakteristik Individu dan Karakteristik Pekerjaan dengan Kepuasan Kerja: Studi Kasus pada Karyawan PT Perhutani (Persero) KPH Bogor. Bogor: Tesis Institut Pertanian Bogor.

Istijanto. (2006). Riset Sumber Daya Manusia. Jakarta: PT Gramedia Pustaka Umum.

Johlke, Mark C., Christine L. Stamper and Mary E. Shoemaker. (2002). "Antecedents to Boundary-spanner Perceived Organizational Support". Journal of Managerial Psychology, 17(2), 116-128.

Kadaruddin, Abd. Rahman Kadir, dan Ria Mardiana Y. (2010). Pengaruh Keadilan Distributif, Keadilan Prosedural, dan Keadilan Interaksional Terhadap KepuasanKepuasan Pegawai Pajak di Kota Makassar.

Konrad, Alison M. (2006). "Engaging Employees Through Highinvolvement Work Practices". Ivey Business Journal Online. Reprint\#9B06TB08.

Kuncoro, Muhammad Wahyu. (2012). Penilaian Keadilan Prosedural Ditinjau dari Penilaian Keadilan Interaksional dan Kontrol pada Para Korban Gempa Bumi di Bantul, dalam fpsi.mercubuana.yogya.ac.id. 4 Februari 2013.

Lawler, III, Edward E. (2008). Strategic Talent Management: Lessons from the Corporate World. Madison: Strategic Management of Human Capital: A Project of the
Consortium for Policy Research in Education di University of Wisconsin.

Listyantara, Muhammad Arif. (2009). Pengaruh Keadilan Distributif, Keadilan Prosedural, dan Keadilan Interaksional Terhadap Kepuasan Kerja: Studi Kasus Pada PT. Solo Sentral Taksi. Surakarta: Skripsi Universitas Muhammadiyah Surakarta.

McKenna, Eugene. (2001). Business Psychology and Organizational Behaviour, 3rd Ed. New York: Psychology Press.

Mulyadi, Dudung. (2012). Pengaruh Karakteristik Pekerjaan dan Komitmen Organisasi Terhadap Kinerja Karyawan Pada PT Kirana Surya Perkasa, JMMA, 01(2).

Nugraheni, Fitri, dan Ratna Yulia Wijayanti. (2009). Pengaruh Keadilan Distributif dan Keadilan Prosedural Terhadap Kinerja: Studi Kasus Pada Akademisi Universitas Muria Kudus. Diunduh pada 04 Februari 2013.

Pahlevi, Resa Nur. (2012). Pengaruh Penerapan Metode Reward dan Punishment Terhadap Kinerja Pegawai Negeri Sipil di Badan Kepegawaian dan Diklat Kota Cilegon. Serang: Skripdi di Universitas Sultan Ageng Tirtayasa.

Pati, Surya Prakash and Pankaj Kumar. (2010). Employee Engagament: Role of Self-efficacy, Orgnizational Support \& Supervisor Support. The Indian Journal of Industrial Relations, 46(1).

Rhoades, Linda, Robert Eisenberger, and Stephen Armeli. (2001). "Affective Commitment to the Organization: The Contribution of Perceived Organizational Support". Journal of Applied Psychology, 2001, 86 (5), 825-36. 


\section{Published Volume 20 Nomor 2, Oktober, 2019, 134-145 \\ Jurnal Ilmiah Manajemen dan Bisnis}

ISSN 1693-7619 (print) | ISSN 2580-4170 (online), http://jurnal.umsu.ac.id/index.php/mbisnis

Rhoades, Linda and Robert Eisenberger. (2002). "Perceived Organizational Support: A Review of the Literature". Journal of Applied Psychology, 87(4), 698-714.

Right Management Inc. (2009). Employee Engagement

Organizational Performance.

Riyanto, Makmun. (2008). Faktor-faktor yang Mempengaruhi Keinginan Karyawan Berpindah Kerja. Ragam Jurnal Pengembangan Humaniora, 8(3), 115-21.

Roberts, Roshan Levina. (2005). The Relationship Between Rewards, Recognition, and Motivation At An Insurance Company in The Western Cape. Western Cape: Master tesis di University of the Western Cape.

Robinson, Dilys, Sarah Perryman, and Sue Hayday. (2004). The Drivers of Employee Engagement. Brighton, UK: Institute for Employee Studies.

Sabbagh, Clara. (2003). "The Dimenson of Social Solidarity in Distributive Justice". Social Science Information, 42(2), 255-76.

Sadeli, Jimmy. (2011). Leadership-Driven Model on Employee Engagement: a Social Exchange Perspective. Jakarta: Fakultas Ekonomi Universitas Indonesia.

Saks, Allan M. (2006). Antecedents and Consequences of Employee Engagement. Journal of Managerial Psychology, 21(7), 600-619.

Sawers, Andrew. (2011). The Effects of Perceived Supervisor Support, Organisational Justice and Change Management Strategies in the Context of Organisational Restructuring. Canterbury: Disertasi di University of Canterbury.

Schaufeli, W. B., Bakker, A., \& Salanova, M. (2006). The Measurement of Work
Engagement with a short questionnaire: A Cross-National Study. Educational and Psychological Measurement, 66. 701-716.

Sekaran, Uma. (2006). Metodologi Penelitian untuk Bisnis, Terjemahan: Kwan Men Yon. Jakarta: Salemba Empat.

Santoso, Andreass Ivan. (2011). Pengaruh Karakteristik Pekerjaan Terhadap OCB Melalui Kepuasan Kerja dan Komitmen Organisasi (Studi Pada PT Alam Surya Steel, Sidoarjo). Malang: Skripsi di Universitas Negeri Malang.

Sonnentag, Sabine, Eva J. Moyza, Carmen Binnerwies, and Annika Scholl. (2008). Being Engaged at Work and Detached at Home: A Weeklevel Study on Work Engagement, Psychological Detachment, and Affect. Work and Stress, 22 (3) 257-76.

Spector, Paul E. (2012). Industrial and Organizational Psychology, 6th Ed. Singapore: John Willey \& Sons, Inc..

Subyantoro, Arief. (2009). Karakteristik Individu, Karakteristik Pekerjaan, Karakteristik Organisasi dan Kepuasan Kerja Pengurus yang dimediasi oleh Motivasi Kerja: Studi pada Pengurus KUD di Kabupaten Sleman. Jurnal Manajemen dan Kewirausahaan, 11(1), 11-9.

Tjahjono, Heru Kurnianto. (2007). "Validasi Item-item Keadilan Distributif dan Keadilan Prosedural: Aplikasi Structural Equation Model (SEM) dengan Conformatory Factor Analysis (CFA)", Jurnal Akuntansi dan Manajemen, 18(2), 115-25.

Tuasela, Yane Diana. (2013). "Pengaruh Keadilan Prosedural, Keadilan Distributif, Kepuasan Kerja, dan Komitmen Organisasional Terhadap Perilaku Ekstra Peran 


\section{Published Volume 20 Nomor 2, Oktober, 2019, 134-145 \\ Jurnal Ilmiah Manajemen dan Bisnis}

ISSN 1693-7619 (print) | ISSN 2580-4170 (online), http://jurnal.umsu.ac.id/index.php/mbisnis

(Studi Pada Karyawan PT Bank

BPD Papua KCU Jayapura)" [on-

line]. Abstrak pada repository.unpyk.ac.id/5323/.

Wellins, Richard S., Paul Bernthal, and Mark

Phelps. (2005). Employee

Engagement: The Key to Realizing

Competitive Advantage. White

Paper Development Dimensions International.

Wilson, Karen. (2009). A Survey of Employee Engagement. Kolumbia: Disertasi di University of Missouri.

Wulandari, Purwanti dan Aurik Gustomo. (2012). Analisis Pengaruh Total Returns Terhadap Tingkat Engagement Dosen Institut Teknologi Bandung. http://www.sbm.itb.ac.id/wpcontent/uploads/2010/01/AnalisisPengaruh-Total-ReturnsEngagement-dosen-ITBMANTEK-2011.pdf

Wulandari, Sri. (2011). Pengaruh Afek Positif dan Afek Negatif, Pusat Kendali Internal, dan Keadilan Organisasi Terhadap Perilaku Kewarganegaraan Organisasi Karyawan PT Unindo Jakarta. Yogyakarta: Tesis Magister Manajemen Universitas Gadjah Mada.

Yakin, Mustafa and Oya Erdil. (2012). Relationship between Self-Efficacy and Work Engagement and The Effects on Job Satisfaction: A Survey on Certified Public Accountants. Procedia Social and Behavioral Sciences, 8th International Strategic Managemen Conference, 370-78.

Yoon, Mahn Hee, Jai Hyun Seo and Tae Seog Yoon. (2004). Effects of Contact Employee Sypport on Critical Employee Responses and Customer Service Evaluation". Journal of Services Marketing, 18, 395-412. 